\begin{tabular}{|c|c|}
\hline $\begin{array}{l}\text { MUFOVIL } \\
\text { MENAUEMEN } \\
\text { KEWIRAUSAHAAN }\end{array}$ & $\begin{array}{r}\text { p-ISSN 1858-1048 } \\
\text { e-ISSN 2654-9247 } \\
\text { http://ejurnal.stieipwija.ac.id/index.php/jmk } \\
\text { DOI: } \underline{\text { http://dx.doi.org/10.33370/imk.v17i2.465 }} \\
\text { Jurnal Manajemen Kewirausahaan Vol. 17 No. 02 - Des } 2020 \\
\text { Submit: } 26 \text { Okt 2020; Review: 07 Nov 2020; Publish: } 30 \text { Des } 2020\end{array}$ \\
\hline
\end{tabular}

\title{
ANALISIS TERHADAP FAKTOR-FAKTOR YANG MEMPENGARUHI MINAT BELI KONSUMEN WARDAH COSMETICS
}

\section{(ANALYSIS OF FACTORS AFFECTING CONSUMERS PURCHASE INTENTION ON WARDAH COSMETICS)}

\author{
Oleh: \\ Anik Ariyanti'1); Rochmad Fadjar Darmanto2) \\ ariyanti.anik@yahoo.com ${ }^{1}$; rochmadfadjar@yahoo.co.id $\left.{ }^{2}\right)$ \\ Sekolah Tinggi Ilmu Ekonomi IPWI Jakarta1,2)
}

\begin{abstract}
ABSTRAK
Penelitian ini dilatarbelakangi peningkatan minat beli konsumen pada Wardah Cosmetics yang dipengaruhi oleh beberapa faktor yaitu kualitas produk, label halal, dan brand awareness. Tujuan penelitian adalah mengukur pengaruh kualitas produk, label halal, dan brand awareness terhadap minat beli konsumen Wardah Cosmetics di "Drugstore Skincare" Aeon Cakung. Metode yang digunakan dalam penelitian adalah metode kuantitatif dengan pendekatan asosiatif. Teknik pengambilan data melalui observasi, studi kepustakaan, dan penyebaran kuesioner ke 100 responden. Hasil Uji F diketahui nilai 0,000 < 0,05 sehingga dapat disimpulkan bahwa model persamaan dapat digunakan untuk memprediksi bahwa kualitas produk, label halal, dan brand awareness terbukti berpengaruh terhadap minat beli konsumen. Pembuktikan ini menunjukkan bahwa kualitas produk, label halal, dan brand awareness secara parsial mempunyai pengaruh yang signifikan terhadap minat beli konsumen Wardah Cosmetics.
\end{abstract}

Kata kunci: Brand Awareness; Kualitas Produk; Label Halal; Minat Beli

\begin{abstract}
This research is motivated by an increase in consumer buying interest at Wardah Cosmetics which is influenced by several factors, namely product quality, halal label, and brand awareness. The research objective was to measure the effect of product quality, halal label, and brand awareness on Wardah Cosmetics consumer buying interest at Aeon Cakung's "Drugstore Skincare". The method used in this research is a quantitative method with an associative approach. The technique of collecting data through observation, literature study, and distributing questionnaires to 100 respondents. The $F$ test results show that the value is $0.000<0.05$, so it can be concluded that the equation model can be used to predict that product quality, halal labels, and brand awareness are proven to have an effect on consumer buying interest. This proof shows that product quality, halal label, and brand awareness partially have a significant influence on consumer purchase interest in Wardah Cosmetics.
\end{abstract}

Keywords: Brand Awareness; Halal Label; Product Quality; Purchase Intention

Jurnal Manajemen Kewirausahaan Vol. 17 No. 02 - Desember 2020

LP2M Sekolah Tinggi Ilmu Ekonomi IPWI Jakarta 


\section{PENDAHULUAN}

Dewasa ini industri kosmetik nasional mendapatkan prioritas dari pemerintah Indonesia karena terbukti berperan sangat besar dalam pertumbuhan perekenomian nasional. Industri kosmetik nasional menjadi penyumbang ekspor yang tinggi bagi negara Indonesia sejak 2015 yaitu sebesar USD 818 juta atau dua kali lipat dibandingkan dengan nilai impornya sebesar USD 441 juta. (www.kemenperin.go.id).

Dalam bisnis.com (2016) diuraikan bahwa industri kosmetik nasional saat ini menjadi salah satu industri andalan yang terbukti mampu membukukan rencana perdagangan dalam posisi surplus hingga mendekati $90 \%$. Industri kosmetik diyakini akan menjadi salah satu industri yang strategis potensial. Terdapat 760 perusahaan kosmetik yang tersebar di seluruh Indonesia. Dan di tahun 2017 dapat dilihat perkembangan industri mencapai $56,39 \%$, seperti pada gambar berikut:

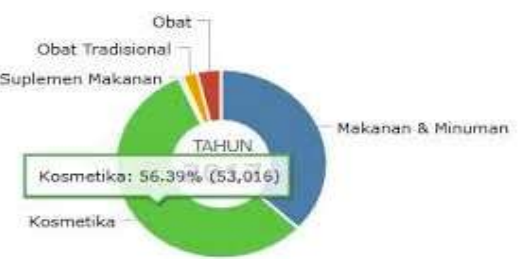

Sumber: openlibrary.telkomuniversity.ac.id Gambar 1. Peningkatan Industri

Kosmetik Indonesia di Tahun 2017

Saat ini bisnis kosmetik di Indonesia makin berkembang dan tumbuh terus berkembang. Menurut data Euromonitor International, bisnis beauty personal care tumbuh rata-rata $9 \%$ per tahun, seperti terlihat pada gambar berikut:

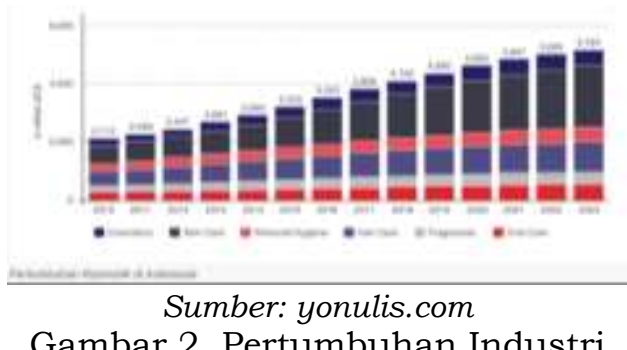

Gambar 2. Pertumbuhan Industri

Kosmetik di Indonesia
Ada banyak faktor yang mempengaruhi pertumbuhan bisnis kosmetik di antaranya meningkatnya pendapatan per kapita masyarakat, promosi, digitalisasi, gaya hidup, dan meningkatnya kebutuhan masyarakat Indonesia terutama wanita dewasa dan remaja. Keanekaragaman produk dan merek yang ditawarkan oleh industri kosmetik di Indonesia sangat mempengaruhi minat membeli konsumen. Perusahaan harus memahami minat beli konsumen, terutama di Indonesia yang mayoritas beragama Islam, konsumennya sangat mengutamakan produk yang halal (dengan Standar MUI).

Sebagai pionir produk kosmetik halal, Wardah semakin berkembang dengan membuat terobosan baru dengan mengeluarkan beraneka ragam produk kecantikan, yang tak hanya bersifat dekoratif (makeup) tapi juga perawatan kulit wajah dan rambut yang cukup berkualitas. Wardah Cosmetics sudah mengantongi Sertifikat Halal dari MUI dan teruji mampu merawat dan mempertahankan kesehatan kulit wajah wanita Indonesia.

Didirikan sejak 1995 oleh Nurhayati Subakat, Wardah yang berada di bawah naungan PT Paragon Technology \& Innovation (PTI) ini memulai perjalanannya dari home industry di kawasan Cibodas, Jawa Barat. Perusahaan selalu mengembangkan formula-formula baru guna menghasilkan produk yang berkualitas, inovatif, dan sesuai dengan kebutuhan dengan harga yang bersaing dengan produk-produk di pasaran.

Persaingan ketat di dunia bisnis kosmetik saat ini, menjadi tantangan tersendiri bagi Wardah Cosmetics. Untuk mempertahankan usahanya dan tetap diminati oleh konsumen, maka Wardah Cosmetics dituntut terus berinovasi dalam menciptakan produk halal yang berkualitas, menjaga brand/merek, penentuan harga, serta promosi penjualan yang menarik melalui media yang ada saat ini atau yang sedang diminati saat ini.

Wardah Cosmetics terus melakukan inovasi dan senantiasa memberikan 
produk yang terbaik untuk konsumennya. Produk unggulannya yang berkualitas adalah produk kecantikan dan perawatan untuk wajah, kulit tubuh, rambut dan perawatan bibir, seperti Make Up Eyebrow Wardah, Make Up Eyeliner Wardah, Make Up Lipstick Wardah, Make Up Liptint Wardah, Make Up Lip Balm Wardah, Make Up Foundation Wardah, Make Up Two Way Cake Wardah, Make Up Loose Powder Wardah, Hair Conditioner Wardah, Body Care Hajj \& Umrah Wardah, Body Care Scentsation Wardah, dan Body Care Body Series Wardah (www.wardahbeauty.com).

Kesemua produk unggulan tersebut sudah mengantongi label halal dari MUI dan telah lolos uji sertifikasi dari BPOM. Harga yang ditawarkan untuk setiap produk unggulan ini bervariasi dan sangat terjangkau untuk kalangan menengah ke bawah dan menengah ke atas.

Saat ini, untuk mendapatkan semua produk Wardah sangat mudah karena sudah tersebar di sejumlah pusat penjualan atau gerai kosmetik di tanah air. Pada tahun 2020 ini PT Paragon Technology and Innovation masih meluncurkan 230 Stock Keeping Unit (SKU) baru dan menambah brand baru yaitu Emina dan Make Over dengan total SKU yang aktif mencapai 400 jenis produk.

Langkah strategis PT Paragon Technology and Innovation dalam penetrasi pasar di 2020 adalah dengan mendorong promosi dan penjualan di berbagai lini, baik ritel maupun digital. Perusahaan meyakini bahwa perkembangan bisnis kosmetik Wardah tetap akan memimpin pasar nasional apabila terus inovasi menghasilkan produk yang berkualitas, menggunakan strategi marketing yang tepat maupun pendistribusian yang baik.

Strategi yang cukup efektif dalam meningkatkan minat beli konsumen adalah dengan mengutamakan kualitas produk, mencantuman label halal, dan brand awareness. Produk yang terbukti berkualitas akan mempunyai pengaruh terhadap minat beli konsumen. Seperti penelitian oleh Karundeng et al. (2019) yang menjelaskan bahwa kualitas produk yang baik merupakan proses terwujudnya minat beli konsumen. Dijelaskan juga bahwa kualitas produk menjadi peran utama dalam meningkatkan minat beli konsumen yang maksimal dan dapat dipercaya. Hal ini sependapat dengan Mulyani et al. (2015) yang mengatakan bahwa kualitas produk berpengaruh signifikan terhadap minat beli ulang konsumen khususnya dalam membeli lipstik merek Wardah di Universitas Tadulako Palu.

Faktor lain yang mempunyai peran dalam mempengaruhi minat beli konsumen adalah pencantuman label halal. Pendapat ini dikuatkan oleh penelitian Aini (2019) yang menyebutkan bahwa labelisasi halal, kualitas layanan, dan promosi secara simultan berpengaruh signifikan terhadap minat beli konsumen Wardah di Salatiga.

Ternyata tidak hanya kualitas produk yang mempengaruhi minat beli konsumen, tetapi brand awareness juga berpengaruh terhadap minat beli konsumen. Pendapat ini didukung oleh Yuliati dan Maulidi (2017) yang mengatakan bahwa brand awareness yang meliputi unaware of brand, brand recognition, brand recall, dan tof of mind secara simultan (bersamaan) berpengaruh signifikan terhadap minat beli konsumen. Brand awareness berpengaruh terhadap minat beli konsumen sebesar 42,6\%.

Semua pendapat tersebut, makin menguatkan alasan peneliti untuk melakukan penelitian dengan masalah yang hampir sama, yaitu menganalisis beberapa faktor yang mempengaruhi minat beli konsumen Wardah Cosmetics pada Konter Drugstore Skincare Aeon Cakung, yaitu dari faktor kualitas produk, label halal, dan brand awareness.

\section{TUJUAN PENELITIAN}

Tujuan penelitian adalah untuk mengetahui faktor-faktor yang meliputi faktor kualitas produk, label halal, dan brand awareness berpengaruh terhadap minat beli konsumen Wardah Cosmetics di Konter Drugstore Skincare Aeon Cakung Jakarta Utara. 


\section{TELAAH LITERATUR DAN PENGEMBANGAN HIPOTESIS Kualitas Produk}

Kualitas produk sangat penting untuk diupayakan perusahaan agar produk yang dihasilkan mampu bersaing dan memenuhi keinginan konsumen. Dengan menciptakan produk yang berkualitas maka perusahaan akan mampu melakukan kegiatan produksi secara efektif dan efisien. Kualitas produk adalah kunci utama agar suatu produk dapat dikenal dan dipercaya masyarakat.

Menurut Assauri (2015:211) bahwa kualitas produk adalah merupakan pernyataan tingkat kemampuan suatu merek atau produk tertentu dalam melaksanakan fungsi yang diharapkan. Pendapat lain mengatakan bahwa kualitas produk adalah: "degree to which $a$ set of inherent characteristics fulfils requirements" yang berarti bahwa kualitas produk adalah derajat yang dapat dicapai oleh karakteristik yang inheren dalam memenuhi persyaratan (Hamdani, 2006:175).

Ada beberapa alasan bagi produsen memproduksi produk yang berkualitas, yaitu sebagai upaya untuk meningkatkan volume penjualan, menjaga loyalitas konsumen, serta meningkatkan produktivitas.

Indikator kualitas produk meliputi kinerja (performance), keistimewaan tambahan (features), keandalan (realibility), kesesuaian dengan spesifikasi (conformance to specifications), daya tahan (durability), dan estetika (asthethic) (Tjiptono, 2010).

\section{Label Halal}

Label sangat berkaitan dengan pemasaran suatu produk. Label halal merupakan pencantuman tulisan atau pernyataan halal yang terdapat pada kemasan produk untuk menunjukkan bahwa produk yang dimaksud berstatus sebagai produk yang halal (Rangkuti, 2018). Syarat kehalalan produk adalah tidak mengandung zat babi dan bahanbahan dari babi, tidak mengandung bahan-bahan yang diharamkan, dan tidak berasal dari hewan yang disembelih yang tidak sesuai syariat Islam. Label halal dapat dicantumkan pada sebuah kemasan yang sudah mendapatkan sertifikasi halal dari BPPOM MUI.

Label halal mempunyai tujuan untuk memberikan kepastian hukum dan perlindungan terhadap konsumen bahkan dapat mempengaruhi minat konsumen untuk membeli suatu produk.

Indikator label halal meliputi gambar tertentu hasil dari tiruan berupa bentuk atau pola, tulisan yang yang bisa dibaca, kombinasi gabungan gambar dan tulisan yang menempel pada kemasan atau sesuai yang melekat-dengan sengaja atau tidak sengaja) pada kemasanpelindung suatu produk. (PP No.69 Tahun 1999 itjen.kemenag.go.id).

\section{Brand Awareness}

Brand awareness atau kesadaran merek adalah suatu kemampuan sebuah merek untuk dapat muncul dalam benak konsumen saat mereka sedang memikirkan kategori produk tertentu atau dengan kata lain adalah seberapa mudah nama produk tersebut dimunculkan (Shimp, 2003). Brand Awareness adalah sasaran komunikasi umum untuk semua strategi promosi (Olson dan Jerry Paul, 2014).

Kesadaran merek juga dapat diasumsikan merek suatu produk dan/atau jasa bias tertanam dalam benak konsumen dan mampu mempengaruh minat beli.

Brand awareness terbagi dalam empat tingkatan yaitu recall, recognition, purchase, dan consumption. Recall adalah seberapa jauh daya ingat konsumen terhadap merek apa saja yang akan mereka ingat, recognition adalah seberapa jauh tingkat pengenalan konsumen terhadap merek, purchase adalah seberapa jauh konsumen memberikan alternatif pilihannya atas produk yang akan mereka beli. Dan consumption adalah seberapa jauh konsumen dalam mengingat merek suatu produk saat mereka sedang menggunakan produk atau layanan pesaing (Suhadi, 2005).

\section{Minat Beli}

Minat beli (purchase intention) berkaitan sekali dengan sikap konsumen 
yaitu keinginan konsumen untuk membeli suatu produk setelah mereka mengamati dan mempelajari produk tersebut. Konsumen berminat untuk membeli akan menunjukkan perhatian dan sikap senang pada produk tersebut.

Menurut Yamit (2001) minat beli adalah langkah evaluasi purna beli atau hasil evaluasi setelah membandingkan dengan apa yang dirasakan sesuai dengan harapannya. Minat beli adalah proses yang harus dilalui oleh konsumen untuk membeli barang atau jasa didasari oleh bermacam-macam pertimbangan (Pramono, 2012).

Beberapa hal yang mempengaruhi minat beli berhubungan dengan perasaan dan emosi. Jika seseorang merasa senang dan puas dalam membeli barang atau jasa, maka hal tersebut akan memperkuat minatnya untuk membeli (Swastha dan Irawan, 2008).

Dua faktor yang mempengaruhi minat beli adalah situasi yang tidak terduga dan sikap terhadap orang lain (Kotler et al., 1999).

Menurut Abdurachman (2004), minat beli dipengaruhi faktor-faktor meliputi kualitas, brand/merek, kemasan, harga, ketersediaan barang, dan acuan. Produk yang berkualitas, brand/merek yang populer dan bernilai, kemasan yang menarik, harga yang layak, produknya mudah diperoleh, dan faktor acuan yang tepat dipastikan minat pembelian konsumen akan meningkat.

Indikator minat beli meliputi minat transaksional yang merupakan kecenderungan seseorang untuk membeli produk. Minat referensial merupakan kecenderungan seseorang dalam meferensikan produk kepada orang lain. Minat preferensial lebih menggambarkan perilaku seseorang yang memiliki preferensi utama pada produk tertentu. Minat eksploratif lebih menggambarkan perilaku seseorang yang selalu mencari informasi mengenai produk yang diminatinya dan untuk mencari informasi dalam mendukung sifat-sifat positif dari produk tersebut (Ferdinand, 2006).

\section{Pengaruh Kualitas Produk terhadap Minat Beli}

Dalam penelitian yang dilakukan Wardani (2015) ditarik kesimpulan bahwa kualitas produk mempunyai pengaruh signifikan terhadap minat beli konsumen muslim pada Jaizah Boutique Tlogosari Semarang (Wardani, 2015). Pendapat ini didukung Febrian (2019) yang mengatakan kualitas produk merupakan variabel yang sangat mempengaruhi minat beli konsumen Lembur Batik.

H1: kualitas produk berpengaruh terhadap minat beli konsumen pada Wardah Cosmetics.

\section{Pengaruh Label Halal terhadap Minat Beli}

Cahyati et al. (2016) menyebutkan dalam penelitiannya bahwa pencantuman label halal terbukti berpengaruh signifikan terhadap minat beli konsumen. Dijelaskan bahwa kehalalan suatu produk menjadi parameter utama dalam proses pemilihan suatu produk. Menurut Widyaningrum (2019) bahwa label halal terbukti mempunyai pengaruh positif dan juga signifikan terhadap minat pembelian kosmetik di lingkungan Civitas Akademika Universitas Muhammadiyah Ponorogo.

H2: label halal berpengaruh terhadap minat beli konsumen pada Wardah Cosmetics.

\section{Pengaruh Brand Awareness terhadap Minat Beli}

Hastuti (2018) dalam penelitiannya menyebutkan bahwa terdapat pengaruh antara kesadaran merek atau brand awareness terhadap minat beli ulang kosmetik Wardah dan pengaruhnya terbukti positif dan signifikan. Diperkuat juga oleh Nurhikmah et al. (2018) bahwa brand awareness berpengaruh positif terhadap minat pembelian konsumen. Minat beli konsumen ini akan timbul apabila mereka sudah merasakan kenyamanan akan suatu produk, merasa puas, dan rasa senang.

H3: brand awareness berpengaruh terhadap minat beli konsumen Wardah Cosmetics. 


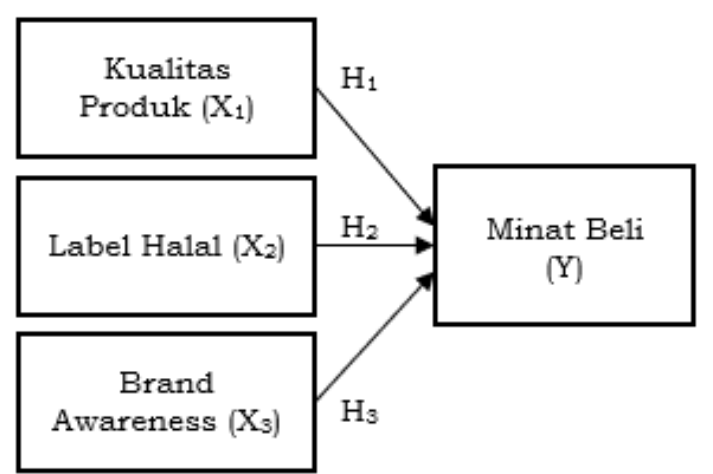

Gambar 3. Kerangka Pemikiran

\section{METODE PENELITIAN \\ Sampel Penelitian}

Teknik pengambilan sampel pada penelitian ini menggunakan nonprobabilty sampling dengan purposive sampling yaitu suatu teknik pengambilan sampel dan sampel dipilih berdasarkan pada pertimbangan tertentu (Sugiyono, 2015). Sedangkan sampel yang dipilih adalah konsumen Wardah Cosmetics Counter Drugstore Skincare Aeon Cakung, yang melakukan pembelian ulang.

Seperti pendapat Supranto (1998) bahwa penelitian yang jumlah populasinya tidak diketahui dapat dihitung dengan rumus sebagai berikut:

$n=\frac{1}{4}\left[\frac{z \propto / 2}{0,1}\right]^{2}$

$n=\frac{1}{4}\left[\frac{1,96}{0,1}\right]^{2}$

$\mathrm{n}=96$

Keterangan:

$$
\begin{array}{ll}
\mathrm{n}: & \text { Jumlah sampel } \\
\underline{Z_{\alpha} / 2}: & \text { Nilai standar daftar luar } \\
& \text { normal standar pada tingkat } \\
& \text { kepercayaan } 95 \% . \\
\mathrm{e} & : \begin{array}{l}
\text { Error maksimal } 10 \%
\end{array}
\end{array}
$$

Dari hasil perhitungan di atas dapat diketahui jumlah sampel yaitu sebesar 96, maka sampel yang digunakan dibulatkan menjadi 100 .

\section{Desain Penelitian}

Penelitian ini menggunakan pendekatan kuantitatif dengan explanatory research jenis kausal yang tujuannya untuk menguji pengaruh variabel independen (kualitas produk, label halal, dan brand awareness) terhadap variabel dependen (minat beli) melalui pengujian hipotesis. Kualitas produk sebagai variabel $\mathrm{X} 1$, label halal sebagai variabel $\mathrm{X} 2$, brand awareness

\begin{tabular}{|c|c|c|}
\hline Variabel & Indikator & Skala \\
\hline $\begin{array}{l}\text { Kualitas Produk } \\
\text { (X1) } \\
\text { adalah suatu } \\
\text { pernyataan tingkat } \\
\text { kemampuan dari } \\
\text { suatu merek atau } \\
\text { produk tertentu } \\
\text { dalam } \\
\text { melaksanakan } \\
\text { fungsi yang } \\
\text { diharapkan. } \\
\text { Assauri (2015) } \\
\end{array}$ & $\begin{array}{l}\text { Meliputi: } \\
\text { - Kinerja } \\
\text { - Features } \\
\text { - Keandalan } \\
\text { - Kesesuaian } \\
\text { dengan } \\
\text { spesifikasi } \\
\text {-Daya tahan } \\
\text {-Estetika } \\
\text { (Tjiptono, 2010) }\end{array}$ & Ordina \\
\hline $\begin{array}{l}\text { Label Halal }\left(\mathbf{X}_{2}\right) \\
\text { adalah } \\
\text { pencantuman } \\
\text { tulisan atau } \\
\text { pernyataan halal } \\
\text { suatu kemasan } \\
\text { produk untuk } \\
\text { menunjukkan } \\
\text { bahwa produk } \\
\text { yang dimaksudkan } \\
\text { berstatus sebagai } \\
\text { produk yang halal. } \\
\text { (Rangkuti, 2018) }\end{array}$ & $\begin{array}{l}\text { Meliputi: } \\
\text { - Gambar } \\
\text {-Tulisan } \\
\text { - Gabungan } \\
\text { gambar dan } \\
\text { tulisan } \\
\text { - Melekat pada } \\
\text { kemasan } \\
\text { (PP No.69 } \\
\text { tahun 1999) }\end{array}$ & Orc \\
\hline $\begin{array}{l}\text { Brand Awareness } \\
\left(\mathbf{X}_{\mathbf{3}}\right) \\
\text { adalah } \\
\text { kemampuan } \\
\text { sebuah merek } \\
\text { dapat muncul di } \\
\text { benak konsumen } \\
\text { saat mereka } \\
\text { sedang } \\
\text { memikirkan } \\
\text { kategori produk } \\
\text { tertentu dan } \\
\text { seberapa mudah } \\
\text { nama produk } \\
\text { tersebut dapat } \\
\text { dimunculkan. } \\
\text { (Shimp, 2003) }\end{array}$ & $\begin{array}{l}\text { Meliputi: } \\
\text { - Recal } \\
\text { - Recognition } \\
\text { - Purchase } \\
\text { - Consumption } \\
\text { (Suhadi, 2005) }\end{array}$ & Ordina \\
\hline
\end{tabular}
sebagai variabel $\mathrm{X} 3$, dan minat beli sebagai variabel $\mathrm{Y}$.

\section{Operasionalisasi Variabel}

Tabel 1. Operasionalisasi Variabel 


\begin{tabular}{|l|l|l|}
\hline \multicolumn{1}{|c|}{ Variabel } & \multicolumn{1}{c|}{ Indikator } & Skala \\
\hline $\begin{array}{l}\text { Brand Awareness } \\
\left(\mathbf{X}_{\mathbf{3}}\right)\end{array}$ & Meliputi: & \\
evaluasi dari & - Minat & \\
purna beli atau & transaksional & \\
hasil evaluasi & - Minat & \\
setelah konsumen & referensial & Ordinal \\
membandingkan & - Minat & \\
apa yang & preferensial & \\
dirasakan dengan & - Minat & \\
harapannya. & eksploratif & \\
(Yamit, 2001) & (Ferdinand, & \\
& 2006) & \\
\hline
\end{tabular}

Sumber: kajian teori

\section{Metode Analisis Data \\ Analisis Deskriptif}

Analisis deskriptif adalah bentuk analisis yang bertujuan untuk memberikan gambaran sifat sesuatu yang tengah berlangsung saat riset dilakukan serta memeriksa sebab-sebab dari suatu gejala tertentu (Umar, 2009). Pada metode deskriprif ini peneliti melakukan pengumpulan, klasifikasi, analisis pada data, dan juga menginterpretasikan untuk memperoleh gambaran yang jelas mengenai permasalahan yang sedang diteliti.

\section{Uji Validitas dan Reliabilitas}

Uji validitas menurut Ghozali (2018) adalah uji untuk melakukan pengukuran atas sah atau valid tidaknya suatu kuesioner. Kriteria pengukuran adalah jika nilai $\mathrm{r}$ hitung $>\mathrm{r}$ tabel dan nilai $(\mathrm{df}=$ $\mathrm{n}-3$ ), maka kuesioner dinyatakan valid. Sebaliknya jika $r$ hitung $<r$ tabel maka kuesioner dinyatakan tidak valid.

Uji reliabilitas adalah suatu alat untuk mengukur kuesioner yang merupakan indikator dari perubah atau konstruk. Kuesioner disebut reliabel atau handal apabila jawaban dinyatakan konsisten dan stabil dari waktu ke waktu (Ghozali, 2018). Dasar pengambilan keputusan dalam uji reliabilitas adalah jika nilai Cronbach's Alpha > 0,60 maka kuesioner dinyatakan reliabel atau konsisten.

\section{Uji Asumsi Klasik}

Saat melakukan analisis regresi berganda, diperlukan asumsi klasik meliputi beberapa uji, yaitu meliputi uji normalitas, uji multikolinearitas, uji heteroskedastisitas, dan uji autokorelasi. Model regresi akan dapat dijadikan alat estimasi yang tidak bias jika telah memenuhi persyaratan BLUE (best linear unbiased estimator) yaitu tidak terdapat heteroskedastisitas, tidak terdapat multikolinearitas, dan juga tidak terdapat autokorelasi (Sudrajat, 2011).

\section{Regresi Linier Berganda}

Analisis regresi linier berganda ini bermanfaat untuk mengukur pengaruh antara lebih dari satu variabel prediktor atau variabel bebas (independent) terhadap variabel terikat (dependent).

\section{Uji Signifikan Parameter Individual (Uji $t)$}

Uji signifikansi parameter individual bertujuan untuk mengukur pengaruh satu variabel independent secara individual dalam menerangkan variabel dependent, dengan menggunakan patokan nilai signifikan pada level 0,05 (a $=5 \%$ ). Kriteria nilai adalah jika sig $\mathrm{t}<$ 0,05 , artinya Ho ditolak artinya terdapat pengaruh signifikan satu variabel independent terhadap variabel dependent. Jika sig $t>0,05$ sehingga Ho diterima yang artinya tidak terdapat pengaruh yang signifikan antara satu variabel independent terhadap variabel dependent (Kuncoro, 2013).

\section{Uji Kelayakan Model (Uji F)}

Uji kelayakan model (goodness of fit) mempunyai tujuan mengukur ketepatan fungsi regresi sampel dalam menaksir nilai aktual secara statistik yaitu nilai statistik $\mathrm{F}$ dengan syarat jika $\mathrm{p}$-value < 0,05 maka uji model layak untuk digunakan dalam penelitian dan jika $\mathrm{p}$ value $>0,05$ maka uji model dinyatakan tidak layak untuk digunakan dalam penelitian (Ghozali, 2018).

\section{Koefisien Determinasi (R2)}

Koefisien determinasi bertujuan untuk pengukur kontribusi atau besarnya sumbangan variabel bebas terhadap variabel terikat. Sugiyono (2015) mengatakan bahwa nilai koefisien determinasi berada antara 0 dan 1, jika nilai mendekati angka 1 maka variabel 
bebas semakin baik dalam menjelaskan variabel terikat.

\section{HASIL DAN PEMBAHASAN \\ Hasil Penelitian \\ Karakteristik Responden}

Karakteristik responden dalam penelitian ini diukur dari usia, jenis kelamin, dan status. Dari 100 responden dapat diketahui $18 \%$ berusia $>25$ tahun, $40 \%$ berusia antara $26-30$ tahun, $32 \%$ berusia antara 32-40 tahun, dan 10\% berusia < 40 tahun. Sedangkan 89\% berjenis kelamin wanita dan $11 \%$ berjenis kelamin laki-laki. Para responden dominan berstatus sudah menikah yaitu $55 \%$ sedangkan yang belum menikah $45 \%$.

\section{Analisis Deskriptif}

Tabel 2. Descriptive Statistics

\begin{tabular}{|l|r|r|r|}
\hline & Mean & Std. Deviation & N \\
\hline Minat Beli & 37.85 & 3.298 & 100 \\
Kualitas Produk & 36.89 & 4.148 & 100 \\
Label Halal & 36.90 & 3.953 & 100 \\
Brand Awareness & 35.84 & 4.254 & 100 \\
\hline
\end{tabular}

Sumber: Data penelitian diolah SPSS, 2020

Tabel di atas menunjukkan nilai mean untuk minat beli sebesar 37,85 , kualitas produk sebesar 36,89, label halal sebesar 36,90, dan brand awareness sebesar 35,84. Standar deviasi untuk masing-masing variabel menunjukkan nilai lebih rendah daripada nilai rata-ratanya sehingga dapat dikatakan bahwa semua sebaran untuk variabel independen hampir sama.

\section{Uji Validitas dan Reliabilitas}

Untuk melakukan pengujian validitas digunakan program SPSS, dan menghasilkan bahwa $r$ hitung $>r$ tabel artinya semua kuesioner dinyatakan valid. Sedangkan nilai Cronbach's Alpha untuk masing-masing variabel menunjukan nilai di atas 0,60 sehingga semua item masuk pada kategori reliabel atau handal (Sugiyono, 2015).

\section{Uji Normalitas}

Hasil pengujian menunjukkan bukti bahwa titik-titik (data) menyebar di sekitar garis diagonal dan terbukti mengikuti atau mendekati arah garis diagonal. Hal ini berarti bahwa model regresi memenuhi asumsi normal.

\section{Uji Multikolinieritas}

Bahwa nilai tolerance terbukti $>0,1$ dan nilai Variance Inflation Factor (VIF) terbukti bahwa tidak ada satu variabel bebas yang memiliki nilai VIF > 10 . Artinya kualitas produk, label halal, dan brand awareness tidak terjadi masalah multikolieritas.

\section{Uji Heteroskedastisitas}

Hasil pengujian membuktikan bahwa tidak ditemukan pola yang jelas serta titik-titik pada grafik menyebar di atas dan di bawah angka 0 pada sumbu Y sehingga model regresi tidak terjadi masalah heteroskedastisitas.

\section{Uji Autokorelasi}

Pada hasil pengujian diperoleh nilai Dubin Watson sebesar 1,839. Jika dibandingkan nilai table DW pada sig $5 \%$, $\mathrm{N}=100$, dan $\mathrm{k}=3$ berada di antara nilai dU $(1,736)$ dan nilai 4-dU $(2,264)$ artinya tidak terdapat autokorelasi.

\section{Analisis Regresi}

Hasil olahan SPSS menunjukkan:

Tabel 3. Analisis Regresi

\begin{tabular}{|c|c|c|c|c|c|}
\hline \multirow[b]{2}{*}{ Model } & \multicolumn{2}{|c|}{$\begin{array}{l}\text { Unstandardized } \\
\text { Coefficients }\end{array}$} & \multirow{2}{*}{\begin{tabular}{c|}
$\begin{array}{c}\text { Standardi } \\
\text { zed } \\
\text { Coefficien } \\
\text { ts }\end{array}$ \\
\\
Beta
\end{tabular}} & \multirow[b]{2}{*}{$t$} & \multirow[b]{2}{*}{ Sig. } \\
\hline & B & $\begin{array}{l}\text { Std. } \\
\text { Error }\end{array}$ & & & \\
\hline 1 (Constant) & 12.470 & 3.038 & & 4.105 & .000 \\
\hline Kualitas Produk & .190 & .074 & .238 & 2.552 & .012 \\
\hline Label Halal & .364 & .078 & .436 & 4.674 & .000 \\
\hline Brand Awareness & .138 & .060 & .178 & 2.287 & .024 \\
\hline
\end{tabular}

Tabel di atas menjelaskan bahwa: $\mathrm{Y}=12,470+0,190 \mathrm{X} 1+0,364 \mathrm{X} 2+0,138 \mathrm{X} 3$ $\mathrm{b}_{1}=0,190$ dengan nilai sig sebesar 0,012 $<0,05$, membuktikan kualitas produk mempunyai pengaruh signifikan terhadap minat beli konsumen sebesar 0,190 . Nilai $b_{2}=0,364$ dengan nilai sig $0,000<0,05$, mengartikan bahwa label halal mempunyai pengaruh signifikan 
sebesar 0,364 terhadap minat beli konsumen. Sedangkan $\mathrm{b}_{3}=0,138$ dan nilai sig diperoleh sebesar 0,024<0,05, membuktikan bahwa brand awareness berpengaruh signifikan terhadap minat beli konsumen yaitu sebesar 0,138.

\section{Uji Kelayakan Model (Uji F)}

Hasil dari uji kelayakan model (Uji F) diketahui sebagai berikut:

Tabel 4. ANOVA ${ }^{\mathrm{b}}$

\begin{tabular}{|l|r|r|r|r|r|}
\hline Model & \multicolumn{1}{|c|}{$\begin{array}{c}\text { Sum of } \\
\text { Squares }\end{array}$} & \multicolumn{1}{c|}{ df } & \multicolumn{1}{c|}{$\begin{array}{c}\text { Mean } \\
\text { Square }\end{array}$} & F & Sig. \\
\hline 1 Regression & 479.536 & 3 & 159.845 & 25.695 & $.000^{2}$ \\
Residual & 597.214 & 96 & 6.221 & & \\
Total & 1076.750 & 99 & & & \\
\hline
\end{tabular}

a. Predictors: (Constant), Brand Awareness, Label Halal, Kualitas Produk

b. Dependent Variable: Minat Beli

Sumber: Data penelitian diolah SPSS, 2020

Dari hasil Uji F di atas diketahui nilai $\mathrm{F}=25,695$ dan sig 0,000. Nilai sig $<0,05$ yang mengartikan bahwa model persamaan layak digunakan untuk memprediksi pengaruh variabel kualitas produk, label halal, dan brand awareness terhadap minat beli konsumen atas produk Wardah Cosmetics.

Uji Determinasi $\left(R^{2}\right)$

\begin{tabular}{|l|r|r|r|r|}
\hline \multicolumn{1}{|c|}{ Tabel 5. Uji Determinasi $\left(\mathrm{R}^{2}\right)$} \\
\hline Model & $\mathrm{R}$ & $\mathrm{R}$ Square & $\begin{array}{c}\text { Adjusted R } \\
\text { Square }\end{array}$ & $\begin{array}{c}\text { Std. Error } \\
\text { of the } \\
\text { Estimate }\end{array}$ \\
\hline 1 & $.667^{\mathrm{a}}$ & .445 & .428 & 2.494 \\
\hline
\end{tabular}

Sumber: Data penelitian diolah SPSS, 2020

Dalam tabel di atas menunjukkan nilai Adjusted $\mathrm{R}$ Square sebesar 0,428 $(42,8 \%)$. Hal ini berarti bahwa bahwa kualitas produk, label halal, dan brand awareness terbukti mempunyai peranan dalam mempengaruhi minat beli konsumen yaitu sebesar 42,8\% dan sisanya $(100 \%-42,8 \%=57,2 \%) 57,2 \%$ nya dipengaruhi faktor lain yang tidak ikut diteliti.

\section{Uji Hipotesis Parameter Individual (Uji t)}

Dalam hasil perhitungan diketahui sebagai berikut:
Tabel 6. Uji t

\begin{tabular}{|l|l|l|}
\hline \multicolumn{1}{|c|}{ Variabel } & t hitung & Sig. \\
\hline Kualitas Produk (X1) & 2,552 & 0,012 \\
Label Halal (X2) & 4,674 & 0,000 \\
Brand Awareness (X3) & 2,287 & 0,024 \\
\hline
\end{tabular}

Sumber: Data penelitian diolah SPSS, 202

\section{Pembahasan \\ Pengaruh Kualitas Produk terhadap Minat Beli}

Hasil analisis membuktikan secara nyata bahwa kualitas produk Wardah Cosmetics mempunyai pengaruh signifikan terhadap minat beli konsumennya. Bukti ini mendukung pendapat Wardani (2015) yang juga membuktikan bahwa kualitas produk merupakan variabel yang berpengaruh signifikan terhadap minat beli konsumennya. Semakin berkualitas produk yang dihasilkan suatu perusahaan maka semakin besar minat beli konsumennya. Hal ini memperkuat pendapat Febrian (2019) yang menerangkan bahwa kualitas produk adalah variabel yang dominan mempengaruhi minat beli konsumen.

Semua penelitian di atas memberikan bukti nyata bahwa kualitas suatu produk berpengaruh positif dan siginifikan terhadap minat beli konsumen khususnya konsumen Wardah Cosmetics pada Konter Wardah di "Drugstore Skincare" Aeon Cakung.

\section{Pengaruh Label Halal terhadap Minat Beli}

Hasil analisis membuktikan bahwa label halal mempunyai pengaruh yang signifikan terhadap minat beli konsumen. Pencantuman label halal pada produk Wardah Cosmetics mampu mempengaruhi niat konsumennya untuk melakukan pembelian. Hal ini sependapat dengan Cahyati et al. (2016) dalam penelitiannya yang menyebutkan bahwa pencantuman label halal pada suatu produk memang berpengaruh signifikan terhadap minat beli. Dijelaskan pula bahwa kehalalan (produk yang ada label halal) merupakan parameter utama bagi konsumen dalam pemilihan suatu produk. Pendapat ini diperkuat oleh Widyaningrum (2019) yang mengatakan bahwa label halal 
mempunyai pengaruh yang positif dan signifikan terhadap minat pembelian kosmetik. Hasil penelitian-penelitian tersebut memberikan bukti empiris yang memperkuat pendapat peneliti bahwa label halal sangat berpengaruh terhadap minat beli konsumen Wardah Cosmetics di Konter Wardah pada "Drugstore Skincare" Aeon Cakung.

\section{Pengaruh Brand Awareness terhadap Minat Beli}

Hasil analisis membuktikan juga bahwa brand awareness berpengaruh signifikan terhadap minat beli konsumen pada Wardah Cosmetics. Hasil ini memperkuat pendapat Hastuti (2018) yang mengatakan bahwa kesadaran merek atau lebih dikenal brand awareness mempunyai pengaruh yang positif dan signfikan terhadap minat beli ulang kosmetik. Pendapat ini diperkuat oleh Nurhikmah et al. (2018) yang menyebutkan bahwa brand awareness berpengaruh positif terhadap minat pembelian konsumen. Penelitianpenelitian ini memberikan bukti bahwa kualitas produk yang terbukti secara positif serta signifikan berpengaruh terhadap minat beli konsumennya.

\section{KESIMPULAN \\ Kesimpulan}

Hasil penelitian membuktikan bahwa kualitas produk mempunyai pengaruh signifikan terhadap minat beli konsumen. Pencantuman label halal juga mempunyai pengaruh yang signifikan terhadap minat beli konsumen, dan brand awareness berpengaruh signifikan terhadap minat beli konsumen pada produk Wardah Cosmetics pada Counter Wardah di Drugstore Skincare Aeon Cakung.

\section{Saran}

Wardah Cosmetics harus tetap meningkatkan kualitas produk karena terbukti mempengaruhi minat beli konsumennya. Menciptakan produk yang terus inovasi harus tetap dipertahankan agar menjadi pembeda dengan produk yang sejenis. Label halal yang menjadi ciri khas Wardah
Cosmetics harus tetap dipertahankan sehingga pioner sebagai kosmetik halal tetap terjaga. Wardah Cosmetics yang sudah mempunyai merek ternama di Indonesia tetap harus meningkatkan brand aweraness konsumen. Perlu melakukan langkah-langkah konkrit untuk membangun brand awareness dengan menciptkan kepercayaan pada konsumen dan mencoba cara lain untuk mencapai brand awareness yang lebih luas.

\section{DAFTAR PUSTAKA}

Abdurachman. (2004). Faktor-Faktor yang Menimbulkan Kecenderungan Minat Beli Konsumen Sarung. Jurnal Manajemen \& Kewirausahaan, 6(1). https://doi.org/10.9744/jmk.6.1.p p. $\% 2034-53$.

Aini, A. (2019). Analisis Pengaruh Labelisasi Halal, Kualitas Pelayanan dan Promosi terhadap Minat Beli Konsumen Wardah di Salatiga. Skripsi. IAIN Salatiga. http://erepository.perpus.iainsalatiga.ac.id /id/eprint/5647.

Assauri, S. (2015). Manajemen Pemasaran: Dasar, Konsep, dan Strategi. Jakarta: PT Raja Grafindo Persada.

Cahyati, R., Jonathan, R., \& Hariyadi, R. M. (2016). Pengaruh Pencantuman Label Halal terhadap Minat Beli Luwak White Coffee pada Mahasiswa Fakultas Ekonomi Universitas 17 Agustus 1945 Samarinda. Ekonomia, 5(3).

Febrian, F. (2019). Pengaruh Kualitas Produk dan Harga terhadap Minat Beli Lembur Batik. Jurnal Ekono Insentif. 13(1), 41-55, April 2019. https://doi.org/10.36787/jei/vi3i $\underline{1.86}$

Ferdinand, A. T. (2006). Metode Penelitian Manajemen: Pedoman Penelitian untuk Penulisan Skripsi, Tesis, dan Disertasi Ilmu Manajemen. Semarang: Badan Penerbit Universitas Diponegoro.

Ghozali, I. (2018). Aplikasi Analisis Multivariate dengan Program IBM 
SPSS 25. Semarang: Badan Penerbit Universitas Diponegoro.

Hastuti, F. M. (2018). Pengaruh Kesadaran Merek, Persepsi Kualitas, dan Loyalitas Merek terhadap Minat Beli Ulang Konsumen Wardah. Jurnal Skripsi UII Yogyakarta.

Hamdani, A., \& Lupiyoadi, R. (2006). Manajemen Pemasaran Jasa, Edisi Kedua. Jakarta: Salemba Empat.

Kotler, P., Bower, J., \& Makens, J. (1999). Marketing for Hospitality and Tourism, 2nd ed. New Jersey: Prentice-Hall, Inc.

Karundeng, N., Kalangi, J. A. F., \& Walangitan, O. F. C. (2019). Pengaruh Kualitas Produk terhadap Minat Beli Konsumen pada Home Industry Pia Deisy Desa Kapitu Kecamatan Amurang Barat. Jurnal Administrasi Bisnis, 8(2). pISSN 2338-9605; e-2655-206X.

Kuncoro, M. (2013). Metode Riset untuk Bisnis dan Ekonomi, edisi 4. Jakarta: Erlangga.

Mulyani, M., Zahara, Z., \& Santi, I. N. (2015). Pengaruh Kualitas Produk terhadap Minat Beli Ulang Lipstik Merek Wardah pada Mahasiswa Universitas Tadulako Palu. Jurnal Ilmu Manajemen Universitas Tadulako, 1(3), September 2015 hal.279-286. ISSN 244-3578. https://jimutuntad.com/inde.php Ljimut/article/viewFile/29/29

Nurhikmah, N., Ramadhoni, B., \& Nurinaya, N. (2018). Pengaruh Brand Awareness dan Brand Attitude terhadap Minat Pembelian Konsumen pada Produk Indihome di Wilayah Telekomunikasi (Witel) Makassar. Balance Jurnal Ekonomi, 14(2), Nov 2018. https://doi.org/10.26618/jeb.v14i 2.2075

Pramono, A. G. S., \& Sukmawati, S. (2012). Pertimbangan dalam Membeli Produk Barang maupun Jasa. Jakarta: Intidayu Press.

Rangkuti, Freddy. (2018). Measuring Customer Satisfaction Teknik Mengukur Strategi Meningkatkan Kepuasan Pelanggan. Jakarta: Gramedia Pustaka Utama.
Shimp, T. A. (2003). Periklanan Promosi Aspek Tambahan Komunikasi Pemasaran Terpadu. Jakarta: Erlangga.

Sudrajat. (2011). Dasar-Dasar Penelitian Ilmiah. Bandung: Pustaka Setia.

Sugiyono. (2015). Metode Penelitian Kombinasa (Mix Methods). Bandung: Alfabeta.

Suhadi. (2005). Effective Branding, Bulletin Studi Ekonomi, 13(2).

Supranto, J. (1998). Teknik Sampling untuk Survei dan Eksperimen. Jakarta: Rineka Cipta.

Swastha, B., \& Irawan. (2008). Manajemen Pemasaran Modern. Yogyakarta: Liberty.

Tjiptono, F. (2010). Strategi Pemasaran, Edisi 2. Yogyakarta: Andi Offset.

Umar, H. (2009). Metode Penelitian untuk Skripsi dan Tesis Bisnis, Edisi Kedua. Jakarta: Raja Grafindo Persada.

Wardani, H. S. (2015). Pengaruh Kualitas Produk dan Harga terhadap Minat Beli Konsumen Muslim pada Jaizah Boutique Tlogosari Semarang. Skripsi. Fakultas Ekonomi dan Bisnis Islam UIN Walisongo Semarang.

http://eprints.walisongo.ac.id/545 7/1/112411082.pdf

Widyaningrum, P. W. (2019). Pengaruh Label Halal, Kesadaran Halal, Iklan, dan Celebrity Endorser terhadap Minat Pembelian Kosmetik melalui Variabel Persepsi Mediasi (Studi pada Civitas Akademik Universitas Muhammadiyah Ponorogo). Capital Jurnal Ekonomi dan Manajemen, 2(2), $\quad$ Maret 2019. http://doi.org/10.25273/capital.v $2 \mathrm{i} 2.3984$

Yamit, Z. (2001). Manajemen Kualitas Produk dan Jasa. Yogyakarta: Ekonosia.

Yuliati, A. L., \& Maulidi, R. A. (2017). Pengaruh Tingkat Brand Awareness terhadap Minat Beli Apple iPhone. Jurnal ISEI Business and Management Review, 1(1), 718.

https://doi.org/10.36217/ibmr.v1i $\underline{1}$ 
PP No.69 Tahun 1999 tetang Label dan

Iklan Pangan. itjen.kemenag.go.id

https://yonulis.com

www.bisnis.com

www.kemenperin.go.id/statistik-industri

www.openlibrary.telkomuniversity.ac.id

www.wardahbeauty.com 